\section{PERLINDUNGAN HUKUM TERHADAP TENAGA MEDIS DI WILAYAH PERANG MENURUT HUKUM HUMANITER INTERNASIONAL ${ }^{1}$ Oleh : Ranna Dwi Prastika²}

\begin{abstract}
ABSTRAK
Tujuan dilakukannya penelitiaan ini adalah untuk mengetahui bagaimana Pengaturan perlindungan Tenaga medis di wilayah perang menurut Hukum Humaniter Internasional dan bagaimana Implementasi Perlindungan Tenaga medis dalam konflik sengketa antar Negara. Dengan menggunakan metode penelitian yuridis normatif, disimpulkan: 1 . Penyerangan tenaga medis merupakan suatu penyerangan sengaja yang termasuk sebagai pelanggaran berat hukum humaniter internasional karena tidak sesuai dengan tujuan dan prinsip-prinsip dasar hukum humaniter internasional. Pelanggaran berat tersebut merupakan suatu kejahatan perang karena dilakukan secara illegal dan melanggar ketentuan dari Pasal 11 Ayat (I) Protokol Tambahan I 1977 yang menyebutkan bahwa "Medical units and transports shall be respected and protected at all times and shall not be the object of attack" Yang menyatakan bahwa kesatuan-kesatuan dan angkutan-angkutan kesehatan harus dihormati dan dilindungi setiap waktu dan tidak boleh menjadi obyek serangan. 2. Kurang efektifnya implementasi ketentuan Konvensi Jenewa 1949 dan Protokol Tambahan 1977 saat sengketa, disebabkan karena kurangnya kemauan dan itikad baik dari para pihak yang bersengketa untuk menetapkan dan mematuhi ketentuan Hukum Humaniter Internasional pada saat sengketa terjadi. Ataupun juga dikarenakan alasan-alasan tertentu, sehingga para pihak mengabaikan perlindungan dan kenetralan tenaga medis.

Kata kunci: Perlindungan Hukum, Tenanga Medis, Wilayah Perang, Hukum Humaniter Internasional
\end{abstract}

\section{PENDAHULUAN}

\section{A. Latar Belakang}

Pengaturan mengenai perlindungan terhadap tenaga medis dalam medan perang

\footnotetext{
${ }^{1}$ Artikel Skripsi. Dosen Pembimbing: Harold Anis S.H, MSi, M.H; Dr. Youla O. Aguw S.H, M.H

2 Mahasiswa pada Fakultas Hukum Unsrat, NIM. 16071101147
}

dapat ditemui dalam pasal-pasal Konvensi jenewa dan Protokol tambahannya. Misalnya, sebagaimana diatur pasal 24 Konvensi Jenewa I 1949 ,Pasal 12 (1), Pasal 8, dan Pasal 21 Protokol tambahan II serta Pasal 9 (1) dan Pasal 11 (1) menyatakan bahwa kesatuan-kesatuan dan angkutan-angkutan kesehatan harus dihormati dan dilindungi setiap waktu dan tidak boleh menjadi obyek serangan. Maka tenaga medis harus dihormati dan dilindungi dalam segala keadaan, di antaranya mencangkup seseorang yang ditugaskan, baik permanen maupun sementara, semata-mata untuk pekerjaan medis (mencari, mengumpulkan, mengangkut, membuat diagnosa dan merawat orang yang cedera,sakit, korban kapal karam dan untuk mencegah penyakit). Mereka itu adalah dokter, perawat, jururawat, pembawa usungan. Dan seseorang yang ditugaskan, baik permanen maupun sementara, semata-mata untuk mengelola atau menyelenggarakan kesatuan medis atau pengangkutan medis. Mereka itu adalah administrator, pengemudi, juru masak dan lain-lain. ${ }^{3}$

Konvensi Jenewa ini sebenarnya bukanlah satu-satunya sumber hukum internasional yang mengatur tentang perlindungan terhadap tenaga medis dalam wilayah peperangan. Perlindungan tentang tenaga medis dapat juga ditemui dalam protokol-protokol tambahan terhadap Konvensi Jenewa. Protokol tambahan I tentang perlindungan terhadap korban perang sengketa bersenjata Internasional, dan protokol tambahan II tentang perlindungan terhadap korban sengketa bersenjata Non Internasional. Jadi dapat dikatakan bahwa peraturan di dunia internasional yang mengatur mengenai perlindungan tenaga medis di medan perang adalah konvensi Jenewa ini. ${ }^{4}$ Namun, walaupun telah dicanangkan Konvensi Jenewa, pelanggaran masih sering dialami oleh warga sipil dan tenaga medis. Pelanggaranpelanggaran tersebut masih ada dan terjadi di tengah-tengah masyarakat internasional.

Pada tahun 2018 dunia digemparkan dengan meninggalnya seorang relawan medis perempuan asal Palestina, Razan Al-Najjar setelah ditembak oleh pasukan Israel di Jalur

\footnotetext{
${ }^{3}$ www.dictio.id, Senin, April 2018 "perlindungan hukum bagi tim medis di wilayah konflik" diakses pada tanggal 18 September 2019 4 /bid
} 
Gaza saat menjalankan tugasnya sebagai tenaga medis. Padahal, saat itu dirinya memakai pakaian warna putih yang menandakan dirinya adalah tenaga medis. Seperti diketahui, sesuai Konvensi Jenewa pada tahun 1949, tenag medis mendapat perlindungan ketika berusaha menyelamatkan mereka yang terluka dalam konflik bersenjata.

Akibat dari penyerangan ini, seorang tenaga medis perempuan meninggal dunia dan dunia sekali lagi tidak dapat berbuat banyak mengenai aksi Israel ini. Terbukti tidak ada resolusi yang berarti dapat menghukum Israel.

Berdasarkan uraian di atas, maka penulis tertarik untuk mengangkat persoalan ini ke dalam skripsi berjudul: "Perlindungan Hukum Terhadap Tenaga Medis di Wilayah Perang Menurut Hukum Humaniter Internasional"

\section{B. Perumusan Masalah}

1. Bagaimanakah Pengaturan perlindungan Tenaga medis di wilayah perang menurut Hukum Humaniter Internasional?

2. Bagaimanakah Implementasi Perlindungan Tenaga medis dalam konflik sengketa antar negara?

\section{Metode Penelitian}

Penelitian ini merupakan penelitian normatif (legal research). Peter Mahmud Marzuki menjelaskan bahwa penelitian hukum normatif adalah suatu proses untuk menemukan suatu aturan hukum, prinsip-prinsip hukum, maupun doktrin-doktrin hukum untuk menjawab permasalahan hukum yang dihadapi. Penelitian hukum normatif dilakukan untuk menghasilkan argumentasi, teori atau konsep baru sebagai preskripsi dalam menyelesaikan masalah yang dihadapi. $^{5}$

\section{PEMBAHASAN}

\section{A. Perlindungan Tenaga Medis Saat Perang Menurut Hukum Humaniter Internasional}

Perlindungan hukum terhadap tenaga medis sangat penting untuk diberikan, mengingat pekerjaan tenaga medis yang berada di wilayah sengketa memiliki resiko tinggi. Sengketa bersenjata seperti yang tengah dialami oleh Palestina telah menunjukkan berbagai penyerangan yang disengaja terhadap tenaga

5Peter Mahmud Marzuki,2005, Penelitian
Hukum, Kencana.,hlm.35.

medis dan fasilitas kesehatan yang dilakukan oleh para tentara Israel.

Penyerangan tersebut merupakan suatu pelanggaran berat dari Hukum Humaniter Internasional, dapat dikatakan demikian karena penyerangan terhadap tenaga medis tidak sesuai dengan tujuan dan prinsip dasar atau asas-asas dari Hukum Humaniter Internasional. Hukum Humaniter Internasional merupakan hukum yang mengatur untuk melindungi orangorang yang tidak lagi berpartisipasi dalam perang dan membatasi cara maupun metode perang. ${ }^{6}$

Berdasarkan hal tersebut maka, Hukum Humaniter melindungi tenaga medis sebagai pihak yang tidak berpartisipasi dalam sengketa atau dapat dikatakan sebagai non-kombatan dimana tenaga medis harus setiap saat dihormati dan dilindungi dalam segala keadaan dan tidak boleh dijadikan sebagai objek sasaran serangan oleh pihak yang bersengketa.

Perlindungan Hukum tenaga medis diatur sangat jelas dalam:

a) Pasal 24 Konvensi Jenewa I 1949

Dimana perlindungan bagi tenaga medis telah diatur di dalam Konvensi Jenewa I 1949 Bab IV Pasal 24 yang menyebutkan, bahwa anggota dinas kesehatan yang dipekerjakan khusus untuk mencari atau mengumpulkan, mengangkut atau merawat yang luka dan sakit, atau untuk mencegah penyakit, dan staf yang dipekerjakan khusus dalam administrasi kesatuankesatuan dan bangunan-bangunan kesehatan, demikian juga rohaniwan yang bertugas dalam angkatan perang, harus dihormati dan dilindungi dalam segala keadaan. Personil Palang Merah dan Bulan Sabit Merah dan himpunan yang bersifat netral juga mendapatkan hak yang sama. ${ }^{7}$

b) Pasal 12 (I) Protokol Tambahan I 1977

Dimana perlindungan bagi tenaga medis telah diatur di dalam Pasal 12 Perlindungan satuan - satuan kesehatan. Satuan-satuan kesehatan harus setiap saat selalu dihormati dan dilindungi dan tidak boleh menjadi sasaran serangan. ${ }^{8}$

c) Pasal 9 (1) Protokol Tambahan II 1977
${ }^{6}$ Andrey Sujatmoko,2016, Hukum HAM dan Hukum Humaniter,Jakarta, Rajawali Pers, hlm.171.

7 Konvensi Jenewa I 1949 Bab IV Pasal 24

8 Pasal 12 (I) Protokol Tambahan I 1977 
Dimana perlindungan bagi tenaga medis telah diatur di dalam Pasal 9 (1) Perlindungan bagi anggota-anggota dinas kesehatan dan dinas keagamaan Anggotaanggota dinas kesehatan dan dinas keagamaan harus dihormati dan dilindungi serta disediakan segala bantuan dalam melaksanakan kewajiban mereka. Mereka tidak boleh dipaksa untuk melaksanakan tugas-tugas yang tidak sesuai dengan misi kemanusiaan mereka. ${ }^{9}$

d) Pasal 8 Protokol Tambahan I 1977

Pasal 8 Protokol Tambahan I 1977 menyebutkan apa saja yang termasuk dari fasilitas kesehatan yang harus dilindungi yaitu sebagai berikut: “....misalnya rumahrumah sakit dan satuan-satuan serupa lainnya, pusat-pusat transfusi darah, pusatpusat dan lembaga-lembaga pengobatan pencegahan, depo-depo kesehatan, dan tempat-tempat penyimpanan alat-alat kesehatan dan obatobatan dan satuansatuan tersebut. Satuansatuan kesehatan itu dapat berupa benda tidak bergerak atau bergerak, bersifat tetap atau sementara"10

e) Lambang Tenaga Medis

Perlindungan hukum terhadap tenaga medis diatas dilengkapi dengan perlindungan hukum menggunakan lambang pengenal (distinctive emblems). Lambang pengenal tersebut digunakan tenaga medis untuk membedakan dirinya dari pihak lain yang berada dalam sengketa bersenjata. Lambang pengenal juga berfungsi untuk melindungi tenaga medis dan pelayanan medis dari angkatan bersenjata agar tidak menjadi sasaran serangan.

Lambang Tenaga medis diatur di dalam:

1) Konvensi Jenewa I 1949 Pasal 38 sampai dengan Pasal 44, Pasal 53 dan Pasal 54

2) Konvensi Jenewa II 1949 Pasal 41 sampai dengan Pasal 45

3) Konvensi Jenewa IV 1949 Pasal 18 sampai dengan Pasal 22

4) Protokol Tambahan I 1977 Pasal 18, Pasal 85 dan Pasal 1 sampai dengan Pasal 5
5) Protokol Tambahan II 1977 Pasal 12

Pentingnya lambang pengenal tersebut harus ditampilkan dengan benar, dan hanya mereka yang berwenang untuk menggunakannya secara hukum serta tidak boleh dijadikan sebagai objek serangan. Selain memberikan perlindungan terhadap tiap individu tenaga medis, Hukum Humaniter juga memberikan perlindungan terhadap fasilitas kesehatan yang merupakan tempat bekerjanya tenaga medis. Perlindungan fasilitas kesehatan diperlukan untuk melindungi tenaga medis karena sangat dimungkinkan apabila fasilitas kesehatan menjadi objek sasaran serangan maka secara langsung tenaga medis yang berada di dalam maupun di lingkungan fasilitas kesehatan juga akan menjadi korban dari serangan tersebut.

f) Pasal 21 Protokol Tambahan I 1977 Dan Pasal 11 (1) Protokol Tambahan II 1977.

\section{B. Implementasi Perlindungan Tenaga Medis dalam Konflik Sengketa antar Negara}

Pekerjaan tenaga medis di medan perang merupakan pekerjaan yang sangat berbahaya, namun kehadiran mereka sangat penting bagi keselamatan nyawa para korban konflik tersebut bahkan bisa jadi para tenaga medis tersebutlah yang menjadi korban dari peperangan tersebut. Ketika berusaha menyelamatkan mereka yang terluka dalam konflik tenaga medis mendapat perlindungan, sesuai dengan yang termaktub dalam Konvensi Jenewa 1949. Dengan kata lain bahwa tenaga medis tidak boleh menjadi target serangan. Perlindungan bagi tenaga medis telah diatur di dalam Konvensi Jenewa I 1949 Bab IV Pasal 24 yang menyebutkan "anggota dinas kesehatan yang dipekerjakan khusus untuk mencari atau mengumpulkan, mengangkut atau merawat yang luka dan sakit, atau untuk mencegah penyakit, dan staf yang dipekerjakan khusus dalam administrasi kesatuan-kesatuan dan bangunan-bangunan kesehatan, demikian juga rohaniwan yang bertugas dalam angkatan perang, harus dihormati dan dilindungi dalam segala keadaan. Personil Palang Merah dan

\footnotetext{
${ }^{9}$ Pasal 9 (1) Protokol Tambahan II 1977

10Pasal 8 (e) Protokol Tambahan I 1977
} 
Bulan Sabit Merah dan himpunan yang bersifat netral juga mendapatkan hak yang sama." ${ }^{11}$

Tujuan dari peraturan internasional ini adalah untuk mengurangi dampak kerugian serta korban jiwa akibat perang terhadap warga sipil. Sebagai tenaga medis, mereka hanya berusaha untuk menyelamatkan orang yang menjadi korban perang di daerah konflik. Secara tidak langsung, mereka telah mempertaruhkan nyawa, kebebasan dan menempatkan diri pada situasi berbahaya demi menyelamatkan nyawa orang lain. Itulah mengapa mereka sering dijuluki sebagai "warriors without weapons", kesatria tanpa senjata.

Implementasi perlindungan tenaga medis dapat dilihat dalam konflik Israel dan Palestina, yang merupakan Konflik Internasional dimana melibatkan dua negara, yaitu Palestina dengan Israel, kedua negara tersebut telah meratifikasi Konvensi Jenewa 1949 dan Protokol-protokol tambahannya sehingga kedua negara tersebut diwajibkan untuk menghormati dan menjunjung hukum humaniter internasional.

Implementasi Konvensi Jenewa merupakan jaminan hak asasi manusia saat perang yang tertuang dalam hukum humaniter internasional diharapkan menjadi pengelola dan pengendali efek destruktif konflik bersenjata (meminimalisir jumlah korban manusia maupun bangunan) yang secara tidak langsung mengungkapkan bahwa hukum humaniter internasional tidak dimaksudkan untuk melarang perang atau untuk mengadakan peraturan hukum tentang permainan perang, tetapi karena alasan-alasan perikemanusiaan. Hukum ini memiliki tujuan, yaitu:

a. Memberikan perlindungan terhadap kombatan dan non-kombatan dari penderitaan yang tidak perlu.

b. Menjamin hak asasi manusia yang sangat fundamental bagi mereka yang jatuh ke tangan musuh.

c. Mencegah dilakukannya perang secara kejam tanpa mengenal batas. ${ }^{12}$

\footnotetext{
${ }^{11}$ Adinda Putri Ratna Devi, "Perlindungan Hukum Petugas Medis Dalam Sengketa Bersenjata Non Internasional Di Suriah Menurut Konvensi Jenewa 1949 Dan Protokol Tambahan II 1977", Vol. 1, No. 1, 2014

12Setiono, 2004, Rule Of Law (Supremasi Hukum), Surakarta, Magister Ilmu Hukum Pasca Sarjana Univeristas Sebelas Maret. HIm.35
}

Tenaga medis mendapat perlindungan khusus yaitu tidak dapat diserang dan dijadikan objek perang selama mereka tidak terlibat langsung dalam peperangan. Bahkan didalam Konvensi Jenewa I Bab IV pasal 25 disebutkan "anggota dinas kesehatan juga harus dilindungi dan dihormati apabila mereka sedang melakukan kewajiban-kewajibannya pada saat mereka bertemu dengan musuh atau jatuh ketangan musuh". Penyerangan terhadap tenaga medis merupakan sebuah tindakan yang menyalahi aturan hukum humaniter internasional, dimana para tenaga medis tidak seharusnya diserang ataupun diganggu namun sebaliknya harusnya dihormati serta dilindungi ketika sedang melakukan tugasnya di medan perang dan juga dalam keadaan apapun.

Dalam Konvensi Jenewa I pasal 24, pasal 25 dan Pasal 26, dan dalam Protokol Tambahan II pasal 9 dan pasal 10 telah diatur tentang perlindungan bagi tenaga medis. Dalam Protokol Tambahan II 1977 pasal 9 bahwa anggota-anggota dinas kesehatan harus dihormati dan dilindungi, dan harus diberi segala bantuan yang tersedia bagi pelaksanaan kewajiban-kewajiban mereka dan tidak boleh dipaksa untuk melakukan tugas-tugas yang tidak sesuai dengan misi kemanusiaan mereka, serta tidak dapat diminta untuk memberikan pengutamaan (prioritas) kepada siapapun juga kecuali atas dasar medis (medical ground). ${ }^{13}$ Dijelaskan dalam Konvensi Jenewa I 1949 bahwa serangan yang ditujukan pada tenaga medis dan perangkatnya serta anggota-anggota dinas kesehatan dengan tujuan untuk mencegah dan menghambat tenaga medis dan kesatuan-kesatuan medis dalam menolong dan mengobati para korban perang yang membutuhkan pertolongan medis adalah perbuatan yang dilarang.

Hukum humaniter internasional memiliki dua cabang, dua cabang utama yaitu Konvensi Jenewa 1949 adalah salah satunya. Konvensi Jenewa mencoba untuk mengatur agar suatu perang dapat dilakukan dengan lebih memperhatikan prinsip-prinsip kemanusiaan yang bertujuan untuk memanusiawikan perang. Secara detail Konvensi Jenewa dirancang untuk melindungi personil militer yang tidak dapat lagi terlibat dalam pertempuran dan orang-

\footnotetext{
1314 Protokol Tambahan II 1977 Pasal 9
} 
orang yang tidak terlibat aktif dalam permusuhan serta non-kombatan lainnya termasuk tenaga medis.

Sebenarnya Konvensi Jenewa adalah konvensi yang berlaku bagi setiap sengketa bersenjata, maka tidak ada lagi alasan bagi suatu negara untuk mengelakkan diri dari kewajiban-kewajiban konvensi dengan menyangkal bahwa perang tidak diatur dalam hukum. Tetapi pada kenyataannya di lapangan banyak sekali negara-negara yang masih mengabaikan peraturan ini dengan dalih bahwa mereka tidak meratifikasi perjanjian ini, Israel adalah salah satunya. Beberapa peraturanperaturan di dalam Konvensi Jenewa ini nyatanya telah dilanggar oleh pihak Israel dengan menembak tenaga medis di jalur gaza pada saat aksi damai bertajuk Great Return March yang mengakibat 1 tenaga medis meninggal dunia. Saat kejadian tersebut tenaga medis tersebut telah menggunakan lambang pengenal sesuai dengan yang diatur dalam Konvensi Jenewa. Setelah kejadian tersebutpun tidak ada tindakan hukum yang dijatuhkan bagi Israel maupun personil militer yang melakukan kejahatan tersebut bahkan para pejabat tinggi Israel mengklaim bahwa tindakan yang mereka lakukan tidaklah salah.

Artinya implementasi Konvensi Jenewa 1949 tidak terlaksana sesuai dengan salah satu tujuan diciptakannya Konvensi Ini yaitu untuk melindungi para non-kombatan yaitu penduduk sipil yang di dalamnya termasuk tenaga medis.

Banyak sekali tindakan Israel yang telah mencederai ketentuan hukum humaniter dan termasuk Konvensi Jenewa 1949, dan protokol tambahannya, padahal Israel ikut menandatangani atau meratifikasi Konvensi Jenewa 1949 dan Protokol tambahannya. Israel pernah melakukan penyerangan terhadap kamp pengungsi Palestina, Israel juga melakukan perusakan terhadap fasilitas sipil, seperti rumah sakit, tempat ibadah, rumahrumah penduduk sipil, dan banyaknya penyerangan Israel yang mengenai masyarakat sipil atau rakyat sipil. Apabila suatu negara telah meratifikasi atau telah menandatangani Konvensi Jenewa maka negara tersebut sudah seharusnya mengetahui tenaga medis baik yang tergabung didalam suatu angkatan bersenjata, anggota lembaga kemanusiaan (ICRC), dan lainnya yang menggunakan lambang yaitu lambang palang merah, bulan sabit merah, dan Kristal merah, itu tidak boleh diserang bagaimanapun caranya, dan harus dilindungi dan dihormati ketika mereka sedang menjalankan tugasnya. ${ }^{14}$

Terkait banyaknya kasus pelanggaran terhadap hukum humaniter internasional yang dilakukan oleh Israel, telah banyak kecaman dunia internasional dan telah banyak rekomendasi dan badan penyidik untuk menyelidiki pelanggaran yang dilakukan oleh Israel akan tetapi belum bisa menyeret Israel kedalam pengadilan internasional untuk mempertanggung-jawabkan pelanggaranpelanggaran kemanusiaan atau pelanggaranpelanggaran hukum humaniter. Dari berbagai fakta-fakta tersebut Israel seringkali tidak mentaati ketentuan hukum humaniter internasional sehingga fungsi preventif dari hukum humaniter tidak terpenuhi, kemudian fungsi represif atau penegakan hukum tersebut didalam kasus-kasus pelanggaran ketentuan hukum humaniter dengan salah satu contohnya ialah kasus tertembaknya tenaga medis Palestina juga belum terpenuhi dengan baik.

Adapun faktor-faktor penyebab jarangnya dibentuk pengadilan internasional untuk mengadili Israel adalah: ${ }^{15}$

1. Faktor politik internasional

Tidak dipungkiri didalam hukum internasional, politik internasional memegang peranan penting. Tidak terkecuali didalam hukum humaniter internasional khususnya dibagian penegakan ketentuan hukum humaniter internasional. Sejatinya hukum internasional wajib menciptakan suatu kesetaraan dan keseimbangan antara negara-negara didalam suatu pergaulan internasional. PBB yang salah satu fungsinya ialah sebagai badan atau

\footnotetext{
${ }^{14}$ Kushartoyo Budi Santoso selaku Communication Officer di International Committee of the Red Cross, Hasil wawancara dengan bagian informasi dari ICRC Apabila Negara sudah meratifikasi Konvensi Jenewa 1949 maka negara sudah mengetahui bahwa mereka yang menggunakan lambang tidak boleh diserang pada tanggal 20 November 2018

${ }^{15}$ Adinda Putri Ratna Devi, "Perlindungan Hukum Petugas Medis Dalam Sengketa Bersenjata Non Internasional Di Suriah Menurut Konvensi Jenewa 1949 Dan Protokol Tambahan II 1977", Vol. 1, No. 1, 2014
} 
organisasi yang memberikan pengayoman kepada seluruh masyarakat internasional sudah sebaiknya, sudah seperlunya dan seharusnya memperhatikan negara-negara yang bukan anggota tetap dewan keamanan PBB, atau dengan kata lain negara-negara yang tidak memegang hak veto.

Sejatinya untuk menciptakan kesetaraan dan keseimbangan didalam pergumulan internasional, khususnya didalam penegakan hukum humaniter internasional seperti contohnya penerapan sanksi kepada Israel, tidak perlu ada lagi yang dinamakan Hak Veto. Keberadaan dan penggunaan hak veto sangat mempengaruhi sebuah resolusi yang ingin dibentuk oleh PBB, memang dalam sejarah pembentukan PBB diprakarsai oleh negaranegara yang memenangkan perang dunia ke II, seperti Amerika Serikat, Inggris, Prancis, Russia, dan Republik Rakyat Cina. Negara-negara tersebut mempunyai eksklusifitas yaitu hak veto. Hak veto sendiri ialah sebuah hak untuk melakukan pembatalan keputusan,rancangan peraturan dan perundang-undangan, ketetapan, resolusi yang mana hak ini dimiliki oleh anggota tetap dewan keamanan PBB. ${ }^{16}$

Awal dari munculnya ketidakadaan keadilan didalam tubuh PBB ialah ketika akan diberikan sanksi atau akan dijatuhkan sanksi internasional kepada salah satu pelanggar ketentuan hukum humaniter internasional, seringkali tidak dapat dilaksanakan dikarenakan penggunaan hak veto oleh salah satu pihak yang memilikinya. Pemberian sanksi tidak dapat dilakukan apabila muncul veto, semua tergantung dari politik para pihak. Contoh kongkritnya mengenai banyaknya pelanggaran hukum humaniter internasional yang dilakukan Israel tetapi jarang dilakukan penindakan terhadap Israel adalah dikarenakan sering mendapatkan veto.

Ketika Palestina dan negara-negara didunia mendesak kepada PBB untuk membuat resolusi dan memberikan sanksi kepada
Israel, sering kali salah satu anggota tetap dewan keamanan PBB yang memegang hak veto yaitu Amerika Serikat memveto atau menggunakan hak veto mereka untuk membatalkan resolusi, keputusan, sanksi yang dikeluarkan oleh PBB. Amerika Serikat dan sekutu-sekutunya seperti Inggris tentu akan melindungi Israel secara Israel merupakan salah satu sekutu penting Amerika Serikat di Timur Tengah, tentu saja mereka (Amerika Serikat) berusaha untuk melindungi kepentingan dari Israel, sehingga sering kali ketika akan dikeluarkan resolusi, dan sanksi yang akan dikenakan terhadap Israel, gagal dan tidak dapat diwujudkan karena penggunaan veto yang digunakan oleh salah satu dewan keamanan tetap PBB dalam hal ini Amerika Serikat.

Seharusnya penegakan terhadap hukum internasional khususnya hukum humaniter internasional haruslah ditegakkan secara bersama-sama bukan dengan cara-cara politik dan lobi-lobi politik dalam hal ini negara pemegang hak veto, guna menciptakan keadilan dalam penegakan dan keefektifan ketentuan hukum tersebut.

2. Faktor Negara itu sendiri

Israel merupakan salah satu negara yang ikut meratifikasi Konvensi Jenewa 1949 dan Protokol tambahannya, sehingga seharusnya Israel mengetahui dengan jelas ketentuan-ketentuan hukum perlindungan terhadap korban perang, rakyat sipil terutama tenaga medis, akan tetapi tetap saja banyak sekali pelanggaran baik sengaja maupun tidak sengaja yang dilakukan oleh Israel didalam agresi ke wilayah Palestina.

Prinsip Pembedaan (Distinction Principle) sering kali diabaikan oleh Israel (angkatan bersenjata Israel) terbukti dengan banyaknya kasus penyerangan terhadap rakyat sipil yang berstatus non-kombatan, fasilitas-fasilitas sipil, dan termasuk kasus penembakan perawat Palestina Razan alNajjar baru-baru ini, sehingga akibat tindakan tersebut baik itu sengaja atau tidak sengaja (kecerobohan) menyebabkan implementasi dari Konvensi Jenewa yang ditujukan untuk memberikan perlindungan kepada warga sipil menjadi tidak terimplementasi dengan baik, dan tingkat

$16 \mathrm{Ibid}, \mathrm{hlm} .54$ 
pentaatannya buruk atau rendah. Sesungguhnya perilaku Israel yang tidak membedakan mana yang kombatan dan mana yang non-kombatan merupakan salah satu bentuk dari masyarakat yang barbar, jikalau mereka adalah bangsa atau masyarakat yang beradab tentu saja mereka akan mentaati ketentuan hukum humaniter tersebut dan melindungi rakyat sipil dan relawan kemanusiaan dari dampak agresi militer mereka ke Palestina.

Kemudian rendahnya kemauan dari Israel untuk mengadili pelaku pelanggaran hukum humaniter yang dilakukan oleh pihaknya sendiri, dan sering memberikan alasan guna berdalih bahwa mereka tidak melakukan pelanggaran terhadap ketentuan hukum humaniter internasional tersebut, pelanggaran yang dilakukan oleh Israel ketika melakukan agresi ke wilayah Palestina baru tersentuh apabila sudah ada desakan dari dunia internasional akan tetapi apabila akan dibuat resolusi akan hal itu kembali lagi ke bagian diatas mengenai veto dan politik internasional.

Palestina sendiri mulai tanggal 1 April 2015 sudah meratifikasi dan secara resmi bergabung dengan Mahkamah Kriminal Internasional (ICC) ${ }^{17}$ yang mengkukuhkan Palestina sebagai anggota ke 123 ICC, hal ini dilakukan Palestina sebagai upaya untuk melakukan gugatan terhadap kejahatankejahatan kemanusiaan yang dilakukan oleh Israel. Negara Israel sendiri belum meratifikasi Statuta Roma terkait ICC itu.

Berkaitan dengan teori yang dikemukakan oleh Anthony Allot, didalam konflik Israel dengan Palestina implementasi hukum humaniter terkait perlindungan-perlindungan tenaga medis masih rendah, bukan hanya terjadi pada konflik Israel dan Palestina saja tetapi juga dibanyak konflik yang terjadi diseluruh belahan dunia baik itu konflik yang terjadi pada masa lalu maupun pada beberapa dekade belakangan ini seperti konflik bersenjata di Irak, konflik Syria, konflik bersenjata di Libya, konflik bersenjata di Darfur dan masih banyak lagi.

17 http://m.dw.com/id/palestina-gabung-mahkamahkriminal-internasional/a-18174651 diakses pada tanggal 3 Desember 2019 pukul
Hal ini terjadi dikarenakan masih banyak nya kasus yang terjadi, baik dilakukan secara sadar atau sengaja, maupun akibat kecerobohan sehingga mengakibatkan hilangnya perlindungan terhadap tenaga medis ketika suatu konflik bersenjata terjadi. Sejatinya Konvensi Jenewa 1949 dan Protokol tambahan I dan II tahun 1977 serta protokol tambahan III tahun 2005 masih sangat relevan dalam mengatur konflik bersenjata. ${ }^{18}$

Akan tetapi dalam penegakan Hukum Humaniter tersebut banyak sekali hambatannya seperti yang telah dibahas diatas, apabila hal tersebut terus dibiarkan maka tidak menutup kemungkinan kedepannya akan terjadi lagi kasus-kasus yang mencederai ketentuan hukum humaniter terkait perlindungan non-kombatan ini.

\section{PENUTUP}

\section{A. Kesimpulan}

1. Penyerangan tenaga medis merupakan suatu penyerangan sengaja yang termasuk sebagai pelanggaran berat hukum humaniter internasional karena tidak sesuai dengan tujuan dan prinsipprinsip dasar hukum humaniter internasional. Pelanggaran berat tersebut merupakan suatu kejahatan perang karena dilakukan secara illegal dan melanggar ketentuan dari Pasal 11 Ayat (I) Protokol Tambahan I 1977 yang menyebutkan bahwa "Medical units and transports shall be respected and protected at all times and shall not be the object of attack" Yang menyatakan bahwa kesatuan-kesatuan dan angkutanangkutan kesehatan harus dihormati dan dilindungi setiap waktu dan tidak boleh menjadi obyek serangan.

2. Kurang efektifnya implementasi ketentuan Konvensi Jenewa 1949 dan Protokol Tambahan 1977 saat sengketa, disebabkan karena kurangnya kemauan

\footnotetext{
${ }^{18 K u s h a r t o y o ~ B u d i ~ S a n t o s o ~ s e l a k u ~ C o m m u n i c a t i o n ~ O f f i c e r ~}$ di International Committee of the Red Cross, Hasil wawancara dengan bagian informasi dari ICRC Berdasarkan hasil penelitian yang dilakukan, hukum humaniter internasional dalam menanggapi konflik bersenjata yang terjadi masih sangat relevan dan Konvensi Jenewa 1949 dan Protokol tambahan kedua tahun 1977 masih dapat mengikuti perkembangan konflik yang terjadi di dunia, pada tanggal 20 November 2018.
} 
dan itikad baik dari para pihak yang bersengketa untuk menetapkan dan mematuhi ketentuan Hukum Humaniter Internasional pada saat sengketa terjadi. Ataupun juga dikarenakan alasan-alasan tertentu, sehingga para pihak mengabaikan perlindungan dan kenetralan tenaga medis.

\section{B. Saran}

1. Ditujukan kepada negara yang bersengketa untuk berhenti melakukan serangan terhadap tenaga medis. Upaya yang dapat dilakukan agar penyerangan tenaga medis tidak terjadi lagi di masa yang akan datang yaitu melalui pendidikan militer mengenai Hukum Humaniter Internasional terhadap setiap angkatan bersenjata untuk memahami dan mengetahui sanksi yang di dapat apabila menyerang tenaga medis, serta kepada tenaga medis dan warga sipil agar dapat diberikan sosialisasi terkait Hukum Humaniter Internasional, bahwasanya warga sipil dan tenaga medis mendapatkan perlindungan karena merupakan non-kombatan maka harus selalu dihormati dan dilindungi setiap saat dan tidak boleh dijadikan sebagai objek serangan.

2. Diharapkan kepada negara-negara, terutama kepada Israel yang sedang terlibat konflik dengan Palestina untuk dapat menerapkan ketentuan-ketentuan Hukum Humaniter dalam memberikan perlindungan terhadap tenaga medis yang sedang melaksanakan tugas kemanusiaan dalam wilayah perang. Dan diharapkan juga kepada Dewan Keamanan PBB untuk melakukan reformasi Charter of United Nations terkait hak veto sebagai bentuk agar tugas dan fungsi PBB dapat berjalan optimal dalam hal menjaga perdamaian dan keamanan internasional sehingga PBB harus tegas untuk berupaya menghentikan kejahatan-kejahatan perang dan melindungi korban serta menyelidiki pelaku kejahatan.

\section{DAFTAR PUSTAKA}

Buku:

Ambarwati, 2013, Hukum Humaniter Internasional dalam Studi HubunganInternasional, Jakarta, Rajawali Pers

Allot, Anthony dalam Salim HS dan ErliesSeptianaNurbani, 2013, Penerapan Teori Hukum Pada Penelitian Tesis dan Disertasi, PT.Raja Grafindo Persada,Jakaarta

Dewi, YustinaTrihoniNalestiKejahatan Perang dalam Hukum Internasional dan Hukum Nasional, Jakarta, Raja Grafindo Persada, 2013.

Graham, Evans and Jeffrey Newnham, 1998, ThePenguin Dictionary of International Relations, London: Penguin Books.

Hadjon, Phillipus M. 1987, Perlindungan Hukum Bagi Rakyat Indonesia, Surabaya, PT. Bina Ilmu.

Jawahir,Thontowi dan Pranoto Iskandar, 2006, Hukum Internasional Kontemporer, Bandung: PT RefikaAditama.

Kusumaatmadja, Mochtar, 1968, Konvensi Djenewa Tahun 1949 mengenai PerlindunganKorbanPerang, Bandung, Binatjipta

KPHG.Haryomataram, 2012, Pengantar Hukum Humaniter,Jakarta, Raja Grafindo Persada.

Muchsin, 2003, Perlindungan dan Kepastian Hukum bagi Investor di Indonesia, Surakarta, magister Ilmu Hukum Program Pascasarjana Universitas Sebelas Maret

Permanasari, Arlina, et. all., 1999, Pengantar Hukum Humaniter, Jakarta, International Committee Of The Red Cross (ICRC).

Rusman, Rina 2013, Hukum Humaniter Internasional dalam Studi Hubungan Internasional, Jakarta, Rajawali Pers

Raharjo, Satijipto 2000, Ilmu Hukum, Bandung: PT. Citra Aditya Bakti

Rudy, T.May 2011, Hubungan Internasional kontemporer dan masalah-masalah global, Bandung, PT RefikaAditama.

Sujatmoko, Andrey,2016, Hukum HAM dan Hukum Humaniter, Rajawali Pers, Jakarta. 
Soekanto, Soerjono dan Sri Mamuji,1995,penelitian Hukum Normatif,Suatu Tinjauan Singkat, Raja Grafindo

Setiono, 2004, Rule Of Law (Supremasi Hukum), Surakarta, Magister IImu Hukum Pasca Sarjana Universitas Sebelas Maret

Peraturan Perundang-Undangan:

Charter of United Nations 1945

United Declarations of Human Rights 1948

Geneva Convention 1949

Hague Convention 1907

Protokol Tambahan II 1977 Pasal 9

Peraturan Pemerintah No.32 Tahun 1996

Statuta Roma Mahkamah Pidana Internasional, Elsam, Jakarta, 2000

\section{Website:}

Arti kata perang, http://kbbi.web.id/perang diakses pada 2 Oktober 2019

Kamus Besar Bahasa Indoesia (KBBI) Online,https://kbbi.web.id/perlindu ngan, diakses pada tanggal 5 november 2019

https://tesisdisertasi.blogspot.com, November 2010 "2010-11-pengertian-tenagamedis" diakses pada tanggal 3 Oktober 2019

\section{Skripsi:}

Adinda Putri Ratna Devi, "Perlindungan Hukum Petugas Medis Dalam Sengketa Bersenjata Non Internasional Di Suriah Menurut Konvensi Jenewa 1949 Dan Protokol Tambahan II 1977", Vol. 1, No. 1, 2014 